Temperature Control Using Heat Pipe For HEV Battery 1st Report: Heat Transfer Performance of Heat Pipe

$\begin{array}{rrrrrr}\text { 准 } \bigcirc \text { 西尾 善明 (神户大) } & \text { 正 坂本 俊之 } & \text { (神戸大) } & \text { 正 福田 勝哉 (神戸大) } \\ & & \text { 正 劉 } & \text { 秋生 (神戸大) } & \text { 正 忽那 } & \text { 泰章 (龍谷大) }\end{array}$

Yoshiaki NISHIO, Kobe University, 5-11, Fukaeminami, Higashinada, Kobe

Toshiyuki SAKAMOTO, Kobe University

Katsuya FUKUDA, Kobe University

Qiusheng LIU, Kobe University

Hiroaki KUTSUNA, Ryukoku University

\section{1 模 晋}

ハイブリット電気自動車(HEV)の駆動用電池の寿命には 多くの因子があるが，その中でも温度因子は重要である.

本研究では，ヒートパイプ(1)を利用して, HEV 用駆動 電池を適正な温度に維持することを目的として, 試用ヒ一 トパイプの性能試験を行うとともに，駆動電池をロッドヒ 一夕等で模蝑した装置を用い，ヒー夕発熱量の変化に伴う 温度特性を央験的に求めた。

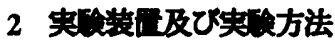

ヒートパイプ熱性能試験では実験装置として，ヒートパ イプ(外径 $9.5 \mathrm{~mm}$, 有効長さ $350 \mathrm{~mm}$ )を用い, 加熱部長さ $115 \mathrm{~mm}$, 断熱部長さ $115 \mathrm{~mm}$, 冷却部長さ $120 \mathrm{~mm}$ に分け, 表面温度測定用に，各部にシート熱電対を取り付けた。加 熱部および邻却部に，それぞれ温水および冷水を流して， 加熱・冷却が出来るようになっている．また，全体を断熱 材で覆った. 上記の実験装置を用いて，(1)熱輸送量，(2) 均 熱性， (3) 熱応答性を求めた。 なお，蒸発部の加熱量を熱 輸送量とした.

各実験方法を以下に述へる. 熱輸送量，均熱性実験では， 冷却水温度 - 流量と屯に一定とし, 温水温度 - 流量を所定 の值に設定し, 各々循環させる. 各部の温度が安定した後, デー夕の計測を 5 秒間隔で 30 回行い，それらの平均値を取 って熱輸送量及び各部の平均温度を算出した.

熱応答性の実験では，まずヒートパイプ全体を泠却水温 度にし，その後，加熱部に温水を流し，各表面温度が定常 になるまでの所要時間を求めた.

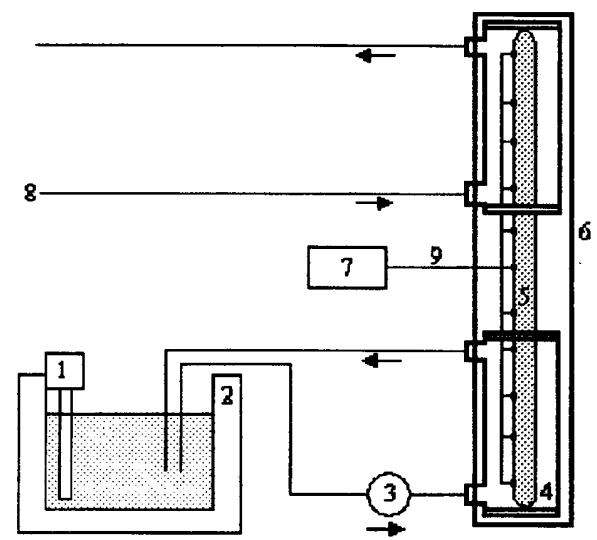

Immersion heater 2. Water bath 3.Pump 4.Acrylic tube 5.Heat pipe 6.Insulation 7.Data logger 8.Tap water 9. Thermo couple

Fig.1 Diagrammatic illustration of experiment.
実験は以下の条件で行った.

Table.1 Experimental conditions.

\begin{tabular}{|l|l|}
\hline Inclination angle & $0^{\circ} \quad$ (水平) $\sim 90^{\circ} \quad$ (垂直) \\
\hline Mass flow rate of heating section & $3.3 \times 10^{-3} \sim 51.7 \times 10^{-3} \mathrm{~kg} / \mathrm{s}$ \\
\hline Mass flow rate of cooling section & $3.3 \times 10^{-3} \mathrm{~kg} / \mathrm{s}$ \\
\hline Water temperature of heating section & $40^{\circ} \mathrm{C} \sim 80^{\circ} \mathrm{C}$ \\
\hline Water temperature of cooling section & $13^{\circ} \mathrm{C} \sim 16^{\circ} \mathrm{C}$ \\
\hline
\end{tabular}

\section{3 実結果及ひ孝察}

\section{1 背抵抗}

Fig2 に, 各加熱部水温 $\left(40^{\circ} \mathrm{C} \sim 80^{\circ} \mathrm{C}\right)$ に対する, ヒ一ト パイプ設置角が $90^{\circ}$ における加熱熱入力之熱抵抗の関係 を 示したものである. 図より加熱部熱入力が増加するに したがって，熱抵抗の值は減少していくことがかかる.

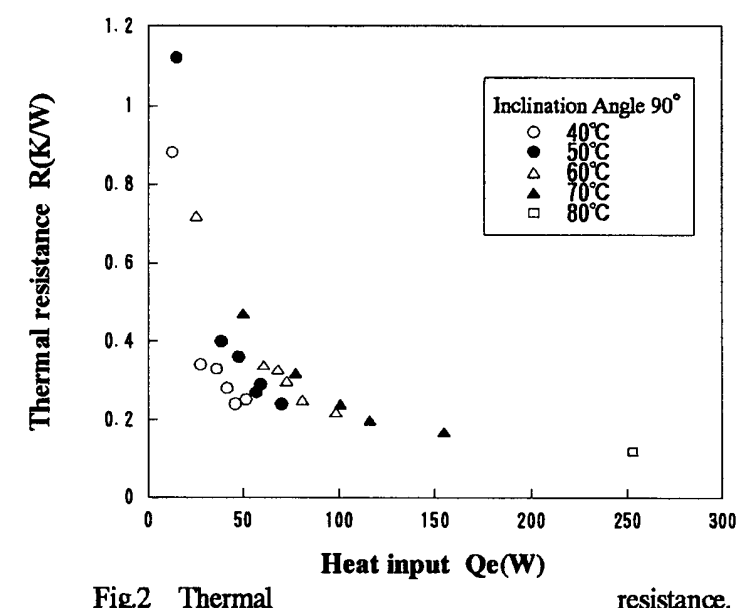

\section{2 均地性}

加熱部での表面温度差は $5^{\circ} \mathrm{C}$ 以内, 冷却部での表面温度 差は $10^{\circ} \mathrm{C}$ 以内であった.

\section{3 等底答性}

加熱部熱入力が約 $150 \mathrm{~W}$ においては，80 秒程で各部表面 温度が定常となった.

\section{4 結至}

（1）熱抵抗は，加熱部熱入力が増加するにしたがって減少 していき，ある一定の值に近つく．

（2）ヒートパイプ表面温度は, 加熱部から冷却部にかけて 下降していくので, 正常に熱輸送が行われた之考えら れる.

\section{格文赫}

（1）日本ヒートパイプ協会 : 実用ヒートパイプ第 2 版日刊工業新聞 